\title{
Developing Leadership Skills in the Classroom
}

\author{
Mohammed Issah and Abdulghani Al-Hattami \\ Bahrain Teachers College, University of Bahrain.
}

\begin{abstract}
There have been calls for pre-service teachers to be equipped with leadership skills. The $2 \mathrm{I}^{\text {st }}$ century urges schools and colleges to prepare the next generation of teachers to have leadership skills and to foster these skills among their students in the classroom. Pre-service teachers need to be equipped with leadership skills to be capable of making real changes in society. This study was conducted to examine to what extent pre-service teachers in Bahrain Teachers College possess leadership skills and the strategies faculty ought to use to improve those skills. A validated survey consisting of eight categories of leadership skills was used to collect the data. The sample consisted of 177 students from different majors (Arabic and Islamic, English, Maths and Science, and Cycle One). The results showed that pre-service teachers possess leadership skills and confirmed developing these skills in the classroom. The pre-service teachers enhanced their leadership skills in planning, problem-solving, self, and other management/controlling, communication, teamwork, decision-making, motivating, evaluation. Furthermore, the participants identified teaching strategies such as group presentation, group work, project-based learning, and problem-based learning as the strategies used by faculty in teaching, which they said facilitates the development of leadership skills in the classroom.
\end{abstract}

Keywords: Leadership skills, Teacher Colleges, Teaching Strategies, ${ }_{21}{ }^{\text {st }}$ Century Skills, Teacher Preparation, Pre-service Teachers, Teacher Leadership, Higher Education

\section{Introduction}

There have been calls for pre-service teachers to be equipped with leadership skills and dispositions for both formal and informal roles (Ado, 
This is a limited preview of the chapter.

To read the full-text chapter, get access by purchasing this chapter or consider buying the complete book. If your library has subscription to EBSCOhost, the chapter including other chapters of the book can be accessed through your library.

This chapter is a part of the book, 'Innovations in Educational Leadership and Continuous Teachers' Professional Development' ISBN (paperback): 978-8I-948483-2-5; ISBN (ebook): 978-8I' $948483-3-2$

Book DOI: https://dx.doi.org/ro.46679/isbn9788194848325 Chapter DOI: https://dx.doi.org/IO.46679/isbn978819484832502 
individuals to think and using the appropriate tools and strategies in the classroom support the development of leadership skills (Cansoy, 20I7; Greenier \& Whitehead, 20I6).

\section{References}

Al-Hattami, A. A., छ̋ Muammar, O. M. (2016). A Psychometric Analysis of an Inventory for Evaluating Students' Leadership Skills. Journal of Teaching Eं Teacher Education (JTTE), 4(2), 97-103.

Ado, K. (20I6). From pre-service to teacher leader: The early development of teacher leaders. Issues in Teacher Education, 25(I), 3-21.

Bennis, W. (2009). On becoming a leader. Basic Books, New York.

Collier, D.A., Rosch, D.M., छ Houston, D.A. (20I7). Effects of participation in formal leadership training in international students compared to domestic students: A national study. Journal of Leadership Education, I6(I2) I48-165. DOI: IоI2806/Vi6/I2/R9.

Cansoy, R. (20I7). The Effectiveness of Leadership Skills Development Program for University Students. Journal of History Culture and Art Research, 6(3), 65-87. DOI:http://dx.doi.org/I0.7596/taksad.v6i3.899

DeBlauw, A.L., छऽ Daugherty, J.L. (20I7). Teaching leadership in technical programs at community colleges. Journal of Leadership Education, I6(I2), 79-9I.

DOI: $1012806 / \mathrm{Vi}_{1} / \mathrm{I}_{2} / \mathrm{R}_{5}$

Goker, S.D. (20I6). Use of reflective journals in development of teachers' leadership and teaching skills. Universal Journal of Educational Research 4(2A), 63-70. DOI:I0.I3I89/ujer.20I6.04I309.

Greenier, V.T., \& Whitehead, G.E.K. (20I6). Towards a model of teacher leadership in ELT: Authentic leadership in classroom practice. RELC Journal, 4 X(I) $79-95$.

Hall, J.L., EBBroyless, T.W. (n.d). Leadership competences of extension agents: Implications for professional development. Journal of Leadership Education, $15(3)$, I87, 200.DOI: 10I2806/VI5/I3/R8.

Holland, J.M., Eckert, J.,छ Allen, M.M. (20I4). From Preservice to Teacher Leadership: Meeting the Future in Educator Preparation, Action in Teacher Education,36(6),433-445, DOI: 10.1080/0I626620.20I4.977738. 
Jackson, T., Burrus, J., Bassett, K., छ ${ }^{3}$ Roberts, R. D. (2010). Teacher leadership: An assessment framework for an emerging area of professional practice. Research Report, Center for New Constructs, Princeton: New Jersey.

Kiersch, C., छु Peters, J. (20I7). Leadership from the inside Out: Student leadership development within authentic leadership and servant leadership frameworks. Journal of Leadership Education, I6(I), I48-I68. DOI: I0I2806/VI6/II/T4.

Kadisha, K. S., ËAlimbekova, A. A. (20I4). Competency Building Approach in Development of Leadership Skills of a To-Be Pedagogue. World Applied Sciences Journal, 30, I49-152

Leeper, L., Tonneson, V.C., छ Williams, R. E. (2010). Preservice Elementary Education Graduate Students' Perception of Teacher Leadership. International Journal of TeacherLeadership, 3(3), I6-3I. ISSN: 1934-9726 http://www.csupomona.edu/ijtl.

Qadri, M.A. (20I6).The Concept of Applied Leadership in the Contemporary World. Journal of Education and Practice, $\lambda$ (4), I7-23. ISSN 2222-288X (Online).

Rogers, C., छ Scales, R. Q (2013). Pre-service Teachers' Perceptions of Teacher Leadership Is It about Compliance or Understanding? Issues in Teacher Education, 22(2), I7' 37 .

Ruiz-Gallardo, J-R., Lopez-Cirugeda, I., छMMureno-Rubio, C. (20I2). Influence of cooperative learning on students' self-perception on leadership skills: A case study in science education. Higher Education Studies, 2(4), 40-47. ISSN 1925-474I E-ISSN 1925, $475 \mathrm{X}$.

Sarzhanoyaa, G.B., Alimbekoyab, A. A., Slambekoyab, T. S, Albytoyab, N.P., छซ Salykzhanovab, S. B. (2016). Information Competence as a Means of Developing Leadership Qualities in Student-Teachers. International Journal of Environmental E' Science Education, $\operatorname{Ir}(9)$, 2887-2899. DOI: 10.12973/ijese.20I6.729a

$\mathrm{Xu}, \mathrm{Y} .,{ }^{2} \mathrm{Patmor}, \mathrm{G}$. (2012). Fostering leadership in pre-service teachers. International Journal of Teaching and Learning in Higher Education, 24(2), 252-256. 